\title{
The Memorial Inscription of the Mosque of Marzuq Al-Ahmadi
}

\section{Ahmad Essam El- Din Mohammad Anwer \\ Guidance Department- Faculty of Tourism and Hotels}

\section{Introduction:}

The revelation of the Holy Qur'an to the Prophet (peace and blessings of Allaah be upon him) in Arabic has had a profound effect that led Muslims to dedicate Arabic writing in their arts with a lot of care and attention. They were able to exert their efforts in this regard, in addition to the nature of Arabic calligraphy and its forms and letters which created many opportunities for improvement and diversification Line to the highest stages of prosperity ${ }^{1}$.

As a result of this interest in Arabic calligraphy that spread its use in time and blessed him, especially in the writing of the Koranic verses on the architectural installations and other artistic monuments, in addition to using it mainly external facades and internal facades overlooking the dish as foundational texts, and this was not only the function of Arabic calligraphy as it became In turn, decorations play a major role in Islamic art. ${ }^{2}$

Arabic calligraphy spread throughout the entire Islamic empire, and it was possible to reach in four centuries to a decorative beauty not reached by another line in the history of mankind and became an essential element of decoration in Islamic arts. Thus, we see that Islamic buildings have a special character, but some of them are distinguished Different and different because of the regions and different eras, in different building materials and in the drawing and types of columns and crowns and contracts and minarets and domes and in the types of materials that cover the walls and geometric, vegetal and clerical decorations that adorn them. ${ }^{3}$

These inscriptions are intended for the inscriptions on the monuments of buildings, stones and artifacts applied or plastic ${ }^{4}$, and were engraved with certain types of lines consistent with the nature of these facilities according to the era in which they were built, and implemented on a range of solid raw materials, which range from plaster to stone, marble and copper Wood and other raw materials 5 . 
It includes, in its entirety, founding texts containing the name of the originator, his titles and functions, the name of the establishment, the purpose of the establishment, the date of commencement and emptiness of the construction, and sometimes the name and title of the supervisor of the building, etc. Effect on different names and purpose of construction. ${ }^{6}$

\section{* Study Importance, the Reasons for its Choice and Study its Objectives:}

\section{- The reasons for selecting the subject and its importance in the field of archaeological studies and tourism guidance:}

1- The desire to collect all the inscriptions of this monument in one study, Tracing these inscriptions in the various references and studies that dealt with those architectural monuments is difficult and exhausting, so, if they are compiled in one study, it will be easy to tackle them.

2- The library of tourist guides lacks similar studies that deal with archaeological inscriptions on monuments as a guiding material.

3- The desire to highlight the importance of these inscriptions in shedding light on the era they represent in general, as they are considered material documents that do not accept questioning or controversy in their information.

4- Increasing the archaeological and tourist awareness of the tour guides and all the workers in the field of guidance in terms of the value of these commemorative inscriptions represented by the paintings and panels. The aim is to take care and preserve them as masterpieces of art which constitute a fundamental aspect of the Islamic cultural and artistic heritage. In addition, they include information indispensible to every tourist guide.

5-To highlight the importance of inscriptions in general and the foundational inscriptions in particular for the easy presentation of their archaeological material and highlighting their importance in the field of tourism guidance.

6- To increase the archaeological and tourist awareness of citizens and tour guides in order to maximize the role of monuments and its archaeological importance. The highlight of such vital areas and their monuments maximize their respect, interest and preservation in order to maximize benefitting from them. This is one of the main objectives of tourism guidance.

7-To identify the types of different scripts and stages of their development, the characteristics of each type, the periods of their prosperity and influences, as well as knowledge of the types of raw materials used in recording these inscriptions on the monuments of the street. This is in addition to identifying the most used scripts in each era. 
8- To address the titles of the inscriptions under investigation and their prosperity in the social life, each in its respective era.

9- To study the contents of these inscriptions, as they provide information on the economic and political situation in the different periods of construction.

10- Facilitate the task of tour guides in terms of reading these inscriptions, knowledge of their content and the distinction between the types of scripts. It is noted that many tourist guides - especially the graduates of the colleges of tourism and archeology - did not pay attention to these inscriptions, which requires focus as well as the presence of specialists. In addition, these inscriptions represent a fertile guidance material as they enrich the guide's archaeological information. 


\section{Brief Overview on the Monument:}

\section{Monument No: $29^{7}$}

The name of the constructed: Al- Amir Ali Bey. Dated: 1043 AH/ 1633 AD.

\section{Al-Amir Ali Bey:}

He is Al- Amir of the Sultan Sharif Sultan in 1043 AH / 1633 AD, where this date falls during the reign of Governor Ahmed Pasha Karji, the Ottoman ruler of Egypt, where he ruled Egypt by order of Sultan Murad Khan in the period from $1043 \mathrm{AH} /$ $1632 \mathrm{AD}$ to $1045 \mathrm{AH} / 1635 \mathrm{AD}$, did not We find sufficient information about this originator, but it is mentioned in some documents that he was from the Mamluk vertebrate community and served as governor of the province of Gerga and Upper Upper Egypt, which was one of the most important regions of Egypt in that period, indicating its high status and great influence. ${ }^{8}$

\section{The Mosque:}

This mosque is located on the street Rahbh Bab Eid on the road to the Palace of thorns and Darb al-Tablawi, as some historical sources indicated that the location of this mosque was the adjacent ruins of the end of Prince Jamal al-Din al-Astadar The mosque to be the center of the Marazigh way, it is said that this mosque is a renovated building and its origin was a school of Prince Mahmoud Turkmani .

In 1043 AH / 1633 CE, Sheikh Hussein Daddah bin Ahmad Al-Manfakji, Sheikh Ahmad Al-Marzouqi carpet, asked Prince Ali Bey to renew his mosque for the possibility of rituals, and to revive the landmarks of the way. Prince Ali Bey accepted his request and prepared a project for renovation. $1045 \mathrm{AH} / 1653 \mathrm{AD},{ }^{10}$ as this collection has a high status for containing a stone painting with the footprints of the Prophet peace be upon him.

\section{The Memorial Inscription of The Mosque:}

The Mosque has a number of inscriptions from Quranic verses and foundational texts as follows:

\section{First: the inscriptions of the Mosqe (from outside):}




\section{1-The inscriptions above the two Maksalas of main entrance:}

Located on the top of the entrance inscriptions, which is a founding text of the madrasa and the dome, Mamluk Thulth prominent in five lines and read: (plate 1).

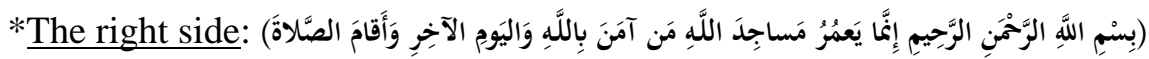

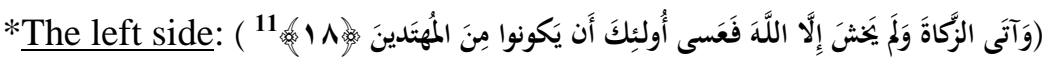

\section{Second: the inscriptions of the Mosque (inside):}

\section{1- Inscription above Qabla Wall:}

The main entrance contains a strip of wooden bazar containing Qur'anic verses in Mumluk thuluth, reads ${ }^{12}$ : (Plate 2).

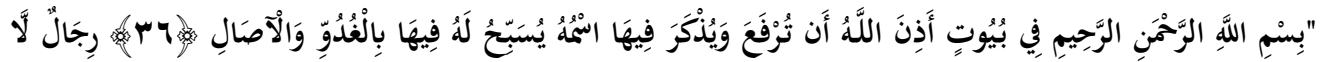

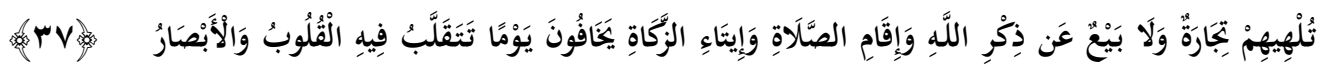

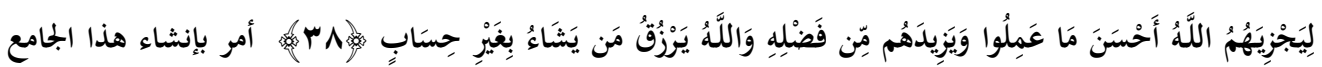

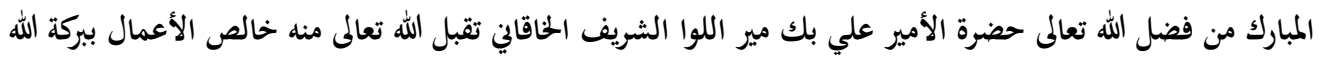
تعالى الكبير المتعال وذلك بمباشرة حضرة مولانا العارف بالله تعلى والدال عليه الفقير إليه تعلى الشيخ حسين دده

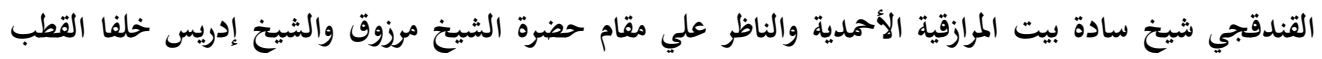

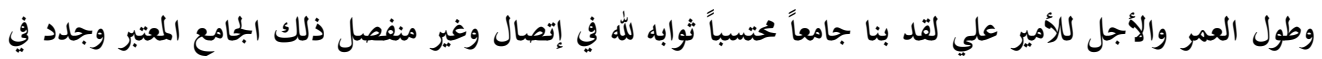

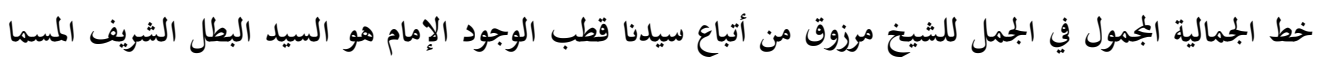

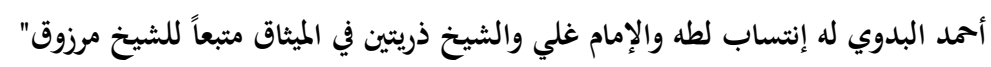

\section{2- Inscription in the middle Rewaq:}

The inscription of this gendarmerie octagon inside the circle with a duplicate white inscribes Mumluk thuluth and read: (Panel 3)

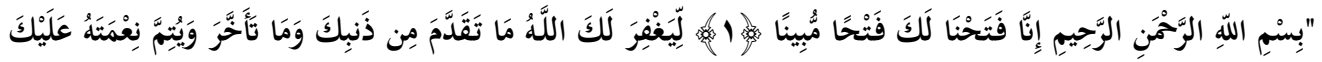

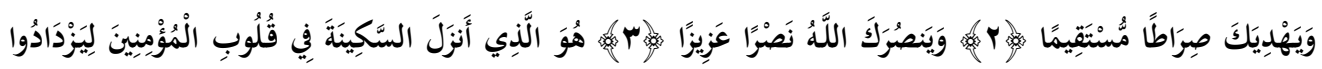

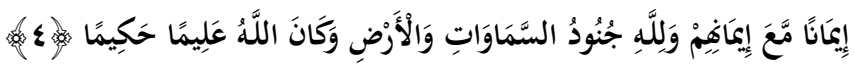

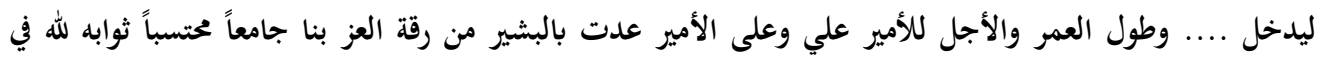

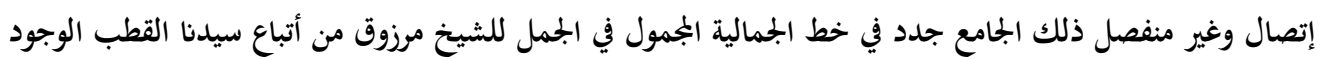

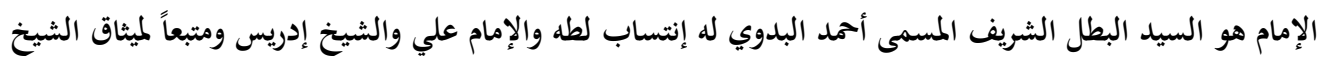

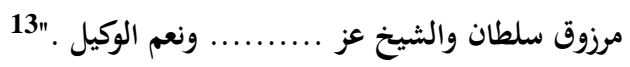




\section{3- Inscription Inner Rewaq:}

On Rewaq of the Mosque are inscriptions of Qur'anic verses carried out with white paint on a wooden floor in a Mumluk Thuluth reads ${ }^{\mathbf{1 4}}$ : (Plates 4).

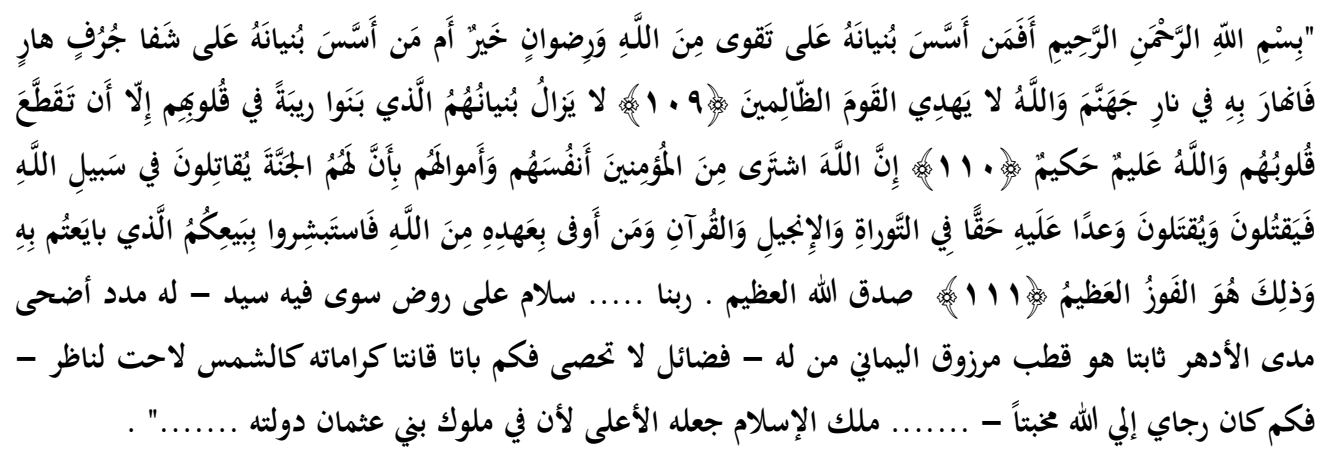

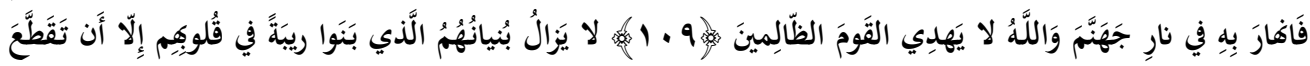

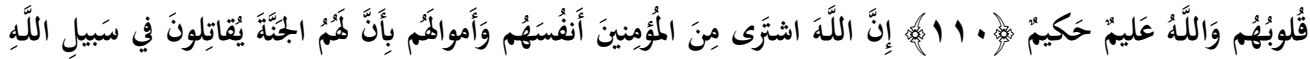

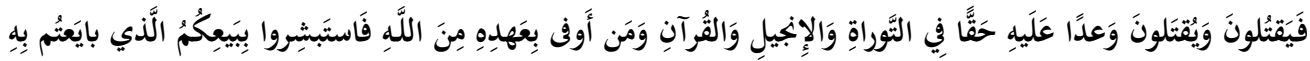

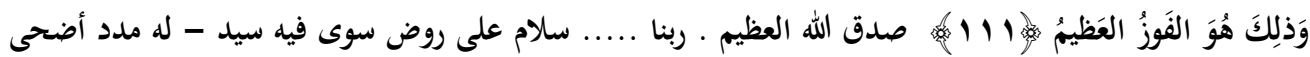

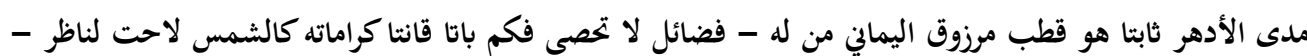

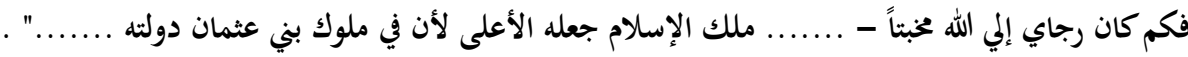

\section{Third: the inscriptions of the Mausoleum (inside):}

\section{1- Inscription of grave-wood of the Mausoleum:}

The mausoleum occupies the southern corner of the mosque, a large room with a shrine in the center of Sheikh Marzouq al-Ahmadi, surrounded by a wooden compartment with inscriptions containing a founding text executed Mumluk Thuluth ,which read ${ }^{15}$ : (Plates 5).

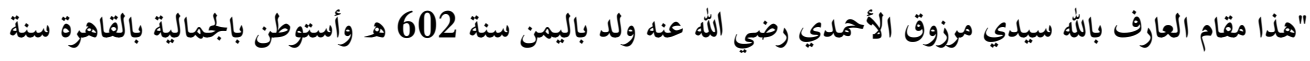
360 هـ الحليفة الأول القطب الكبير سيدي أمد بدوي رضي الله عنه شمسه لاحت لناظر هو القطب مرزوق

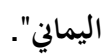

\section{2- Inscription of grave-Marble:}

It was also surmounted by a marble composition, leaving only a cylindrical tomb on which it was inscribed with writings in all its aspects. ${ }^{16}$ : (Plates 6).

* First Line: (لا له

* Second Line: (الا لاله

* Third Line: (حمد رسول)

* Forth Line: (ل)

* Fifth Line: (جدده الفقير الي الله)

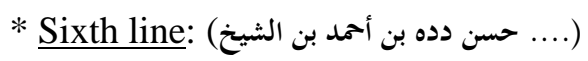

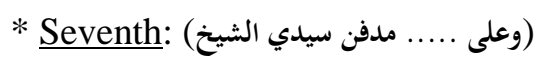




\section{References:}

1 - عاصم محمد رزق : دراسات في العمارة الاسلامية مجموعة ابن مزهر المعمارية بالقاهرة

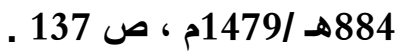

2 - مني محمد زاهر أمين بدير : مدرسة جمال الدين الأستادار ، رسالة ماجستير غير منشورة ،

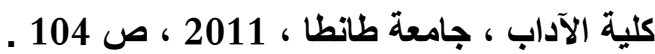

3 - زكى محمد حسن: أطلس الفنون الزخرفية والتصاوير الإسلامية ،مطابع جامعة القاهرة ،

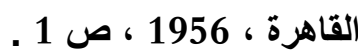

4 - حسن الباثـا : موسوعة العمارة والاثار والفنون الاسلامية ، المجلد الثالث ، ص 216 ـ

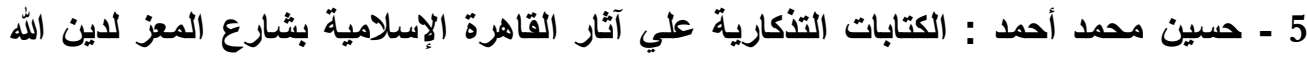

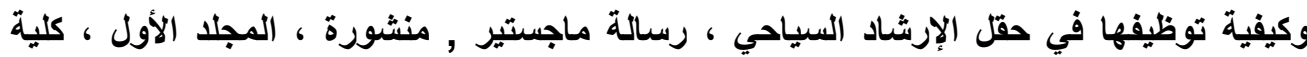

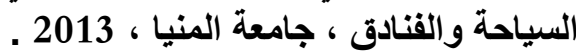
6 - محمد حمزة الداد : بحوث ودراسات في العمارة الإسلامية ،الكتاب الأول، دار نهضة الثرق

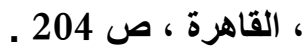

7 - عبد الله عبد الحميد العطار : دليل الآثار الإسلامية بمدينة القاهرة : المجلس الأعلى للآثار ،

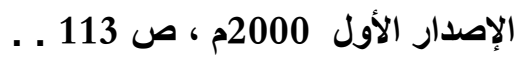

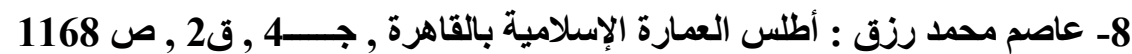

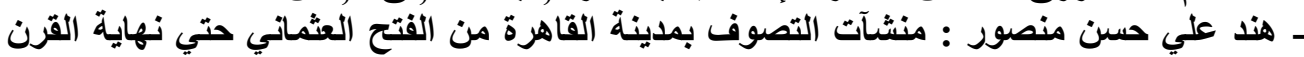
التاسع عشر ، رسالة ماجستير ، غير منشورة , جامعة القاهرة , كلية الآثار , المجلد الأول , 2002

9- He is one of the Hanafi scholars.

10- مروة حسين مرسي : الأثار الإسلامية بحي الجمالية في العصر العثماني ، رسالة ماجستير ,

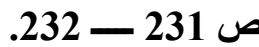
11- قرآن كريم , سورة التوبة , آية 18 ـ

12- Some of these texts were published before. See:

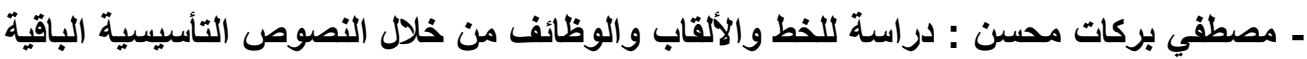

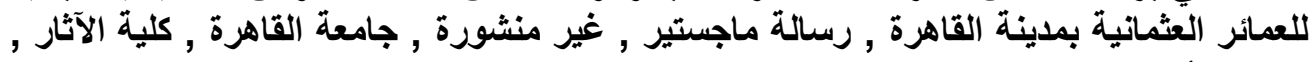
المجلد الأول , 1988 , ص 29 ل 29

13- It is also noted that the text contains the word "Gamalia Street" and may be a rare case to mention a street within the text of renewal may be an advantage distinguish this mosque from other neighboring monuments in the same region. ـ مروة حسين محمد مرسي : المرجع السابق , ص 233 , حاثية 2 . 14- Some of these texts were published before. See: 
ـ حمزة عبد العزيز بلر : أنماط المدفن والضريح , ص 226 / هند علي حسن منصور : منشآت

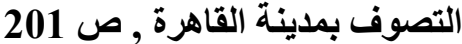

15- Some of these texts were published before. See:

ـ مروة حسين مرسي : الأثار الإسلامية بحي الجمالية في العصر العثماني ، رسالة ماجستير ,ص ص $.232-231$

16- Some of these texts were published before. See:

ـ حمزة عبد العزيز بدر : أنماط المدفن والضريح ,ص 228 .
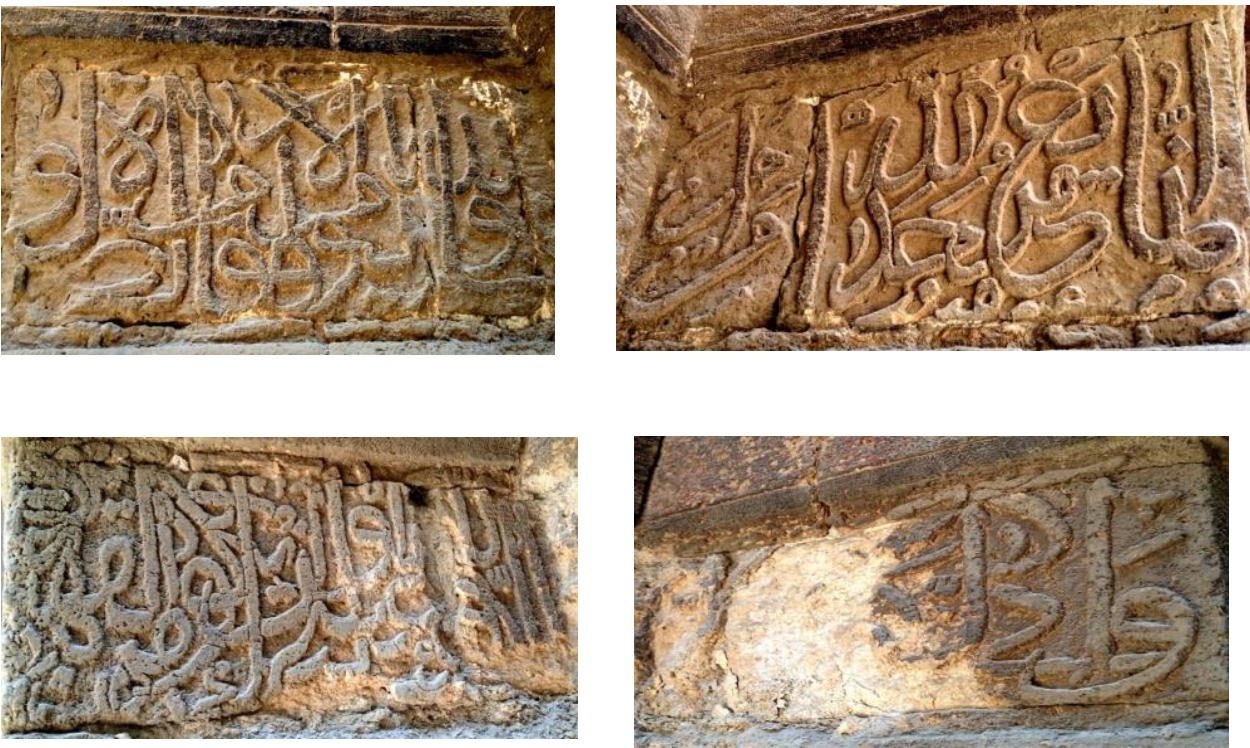

PL (1): Cairo, the the Mosque of Marzuq Al-Ahmadi 1043 AH/ 1633 AD.
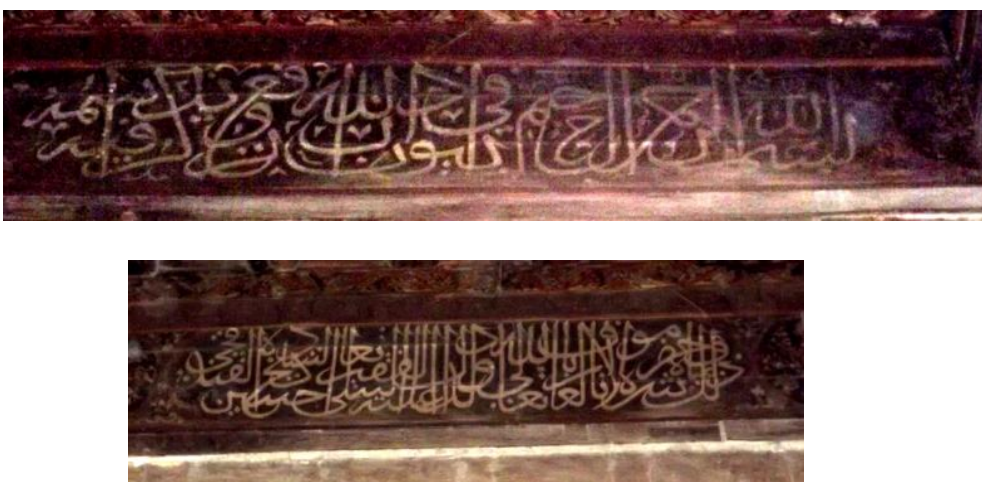
PL (2): Cairo, the the Mosque of Marzuq Al-Ahmadi 1043 AH/ 1633 AD.

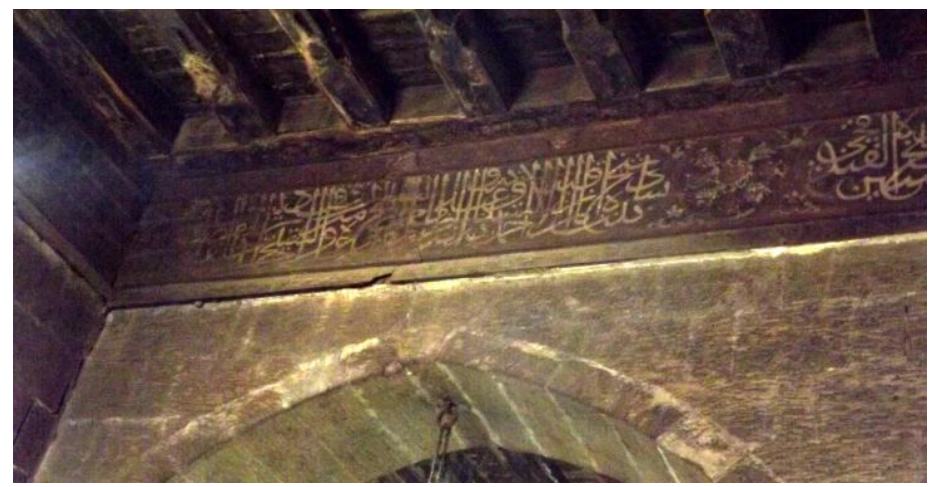

PL (3): Cairo, the the Mosque of Marzuq Al-Ahmadi 1043 AH/ 1633 AD.

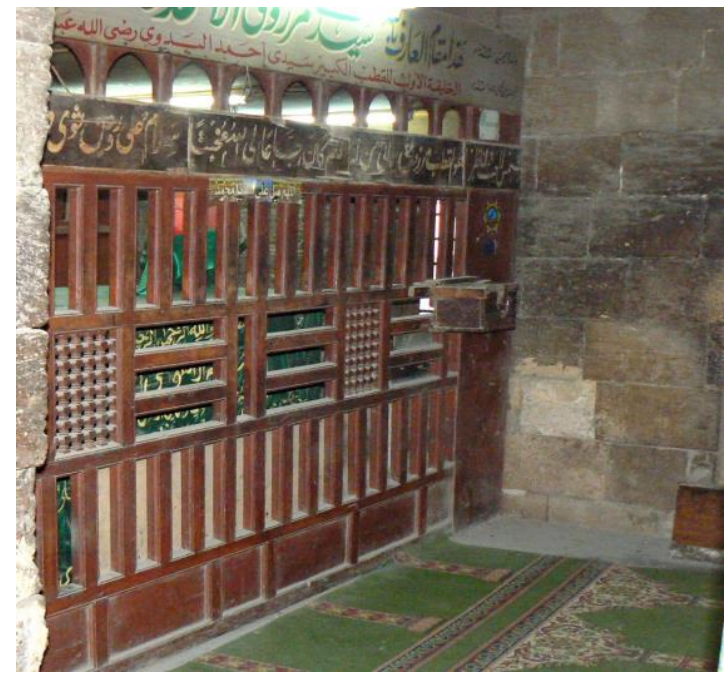


PL (4): Cairo, the the Mosque of Marzuq Al-Ahmadi 1043 AH/ 1633 AD.

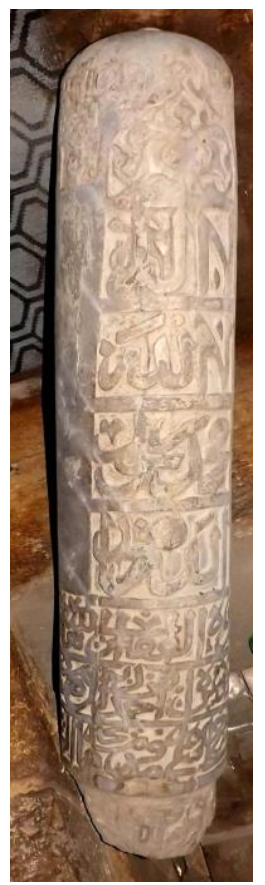

PL (5): Cairo, the the Mosque of Marzuq Al-Ahmadi 1043 AH/ 1633 AD.
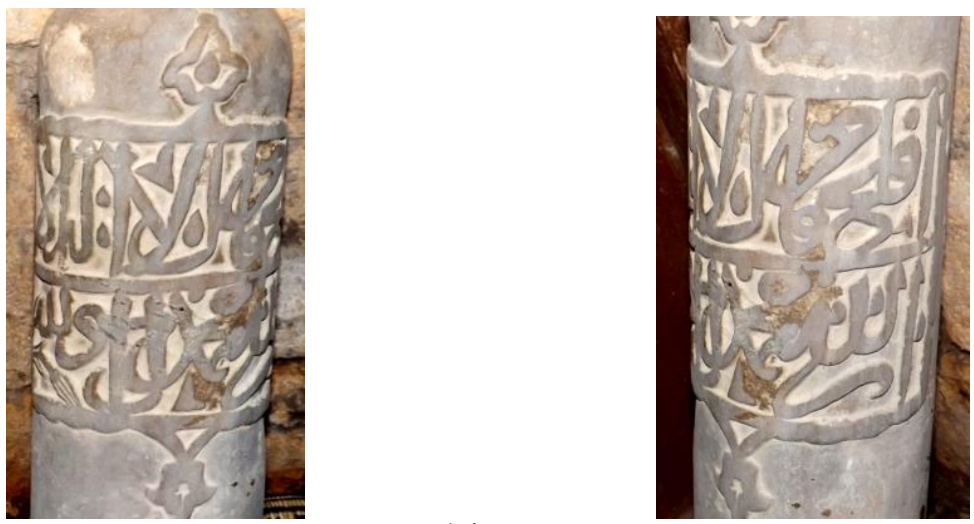
PL (6): Cairo, the the Mosque of Marzuq Al-Ahmadi 1043 AH/ 1633 AD. 


\section{قائمة المصادر والمراجع العربية والأجنبية

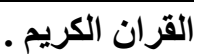

المصادر العربية المطبوعة : المبية

1- 1 ابن اياس : بدائع الزهور فى وقائع الامور ، طبعة مكتبة الشعب 1960م .

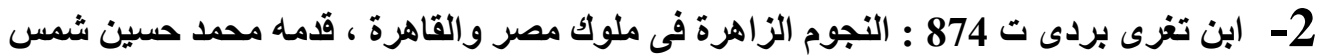

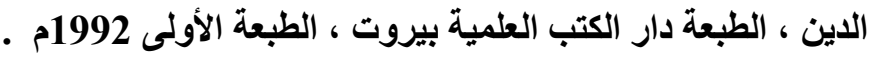

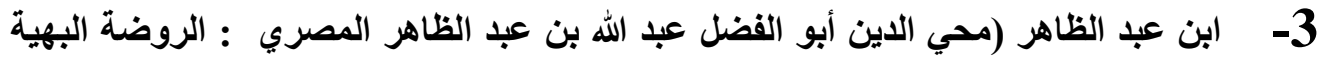

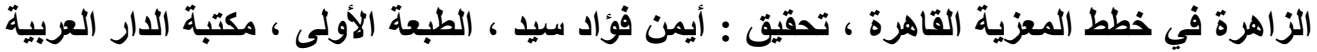

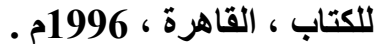

4- الحافظ بن حجر العسقلاني : إنباء الغمر بأبناء العمر , تحقيق : حسن حبثي ، لجنة أحياء

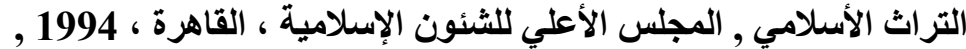

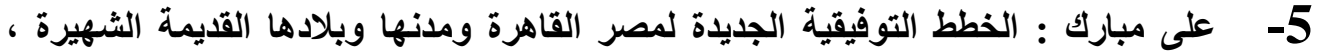

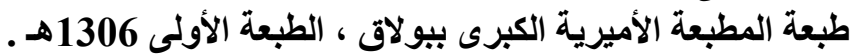

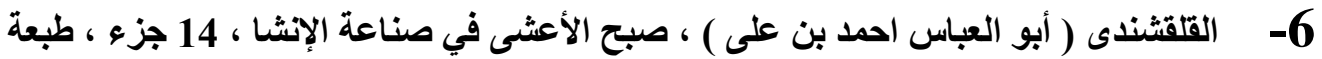

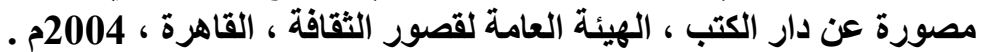

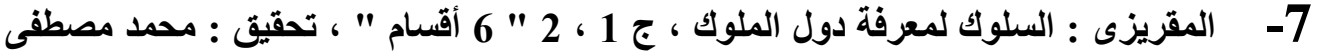

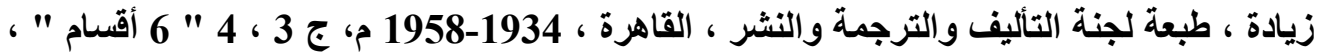
تحقيق : سعيد عبد الفتاح عاشور ، مركز تحقيق التراث ، طبعة دار الكتب المصرية ، القاهرة .1973-1970،

8- حسن الباثـا : موسوعة العمارة والآثار والفنون الإسلامية ، 5 مجلدات، طبعة أوراق شرقية

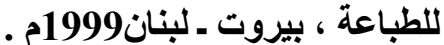

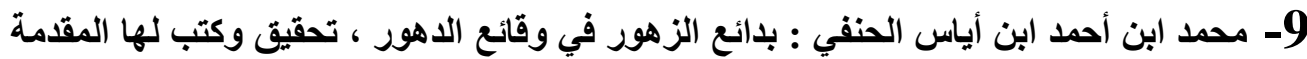

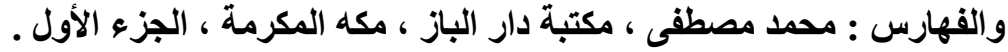

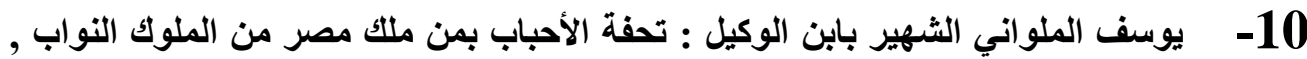
تحقيق : محمد الثشتاوي ، دار الأفاق العربية ، الطبعة الأولي , القاهرة ، 1999 ـ 199

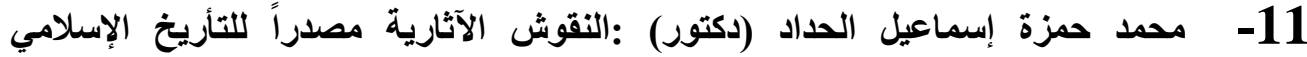

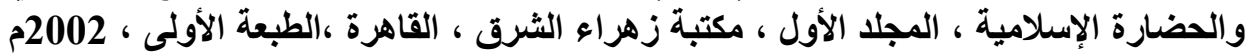

12- زكى محمد حسن: أطلس الفنون الزخرفية والتصاوير الإسلامية ،مطابع جامعة القاهرة ،

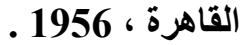

13- عاصم محمد رزق : دراسات في العمارة الاسلامية مجموعة ابن مزهر المعمارية بالقاهرة

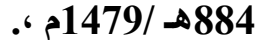

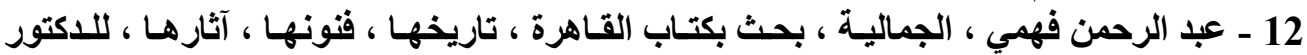

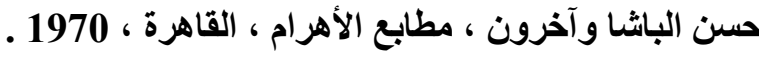


13 - فتحي حافظ الحديدي : التطور العمراني لثوارع مدينة القاهرة من البدايات حتي القرن

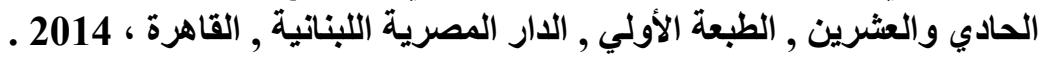

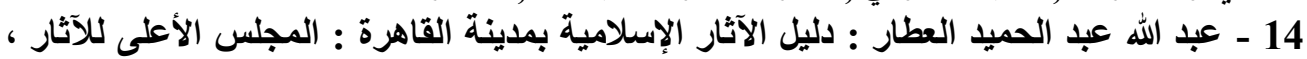

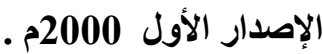

15 - مني محمد زاهر أمين بلئل الإير : مدرسة جمال الدين الأستادار ، رسالة ماجستير غير منشورة ،

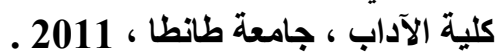

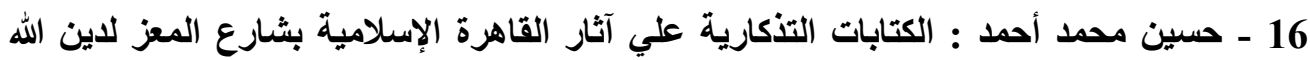

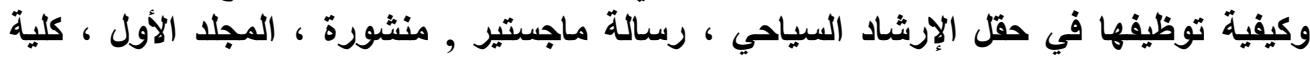

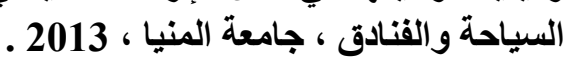

- Hossam Hassan Hemeda .Islamic Archeological Sites In Al-Gammaliva Street, P. 157 - 158. Look:

المصادر الأجنبية :

- M. Van Berchem, Matriaux Pour un corpus inscriptionumarabicarum, maisonarcheologiquefrancais au Caire Tome 3, 1903, PP 494 - 500. 